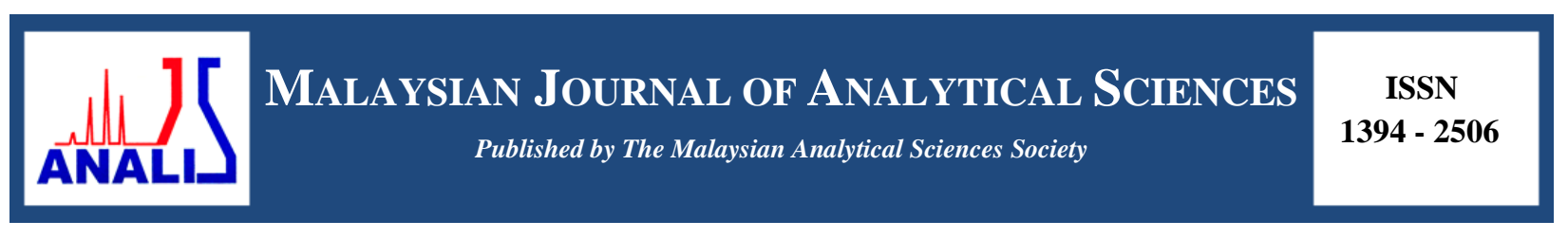

\title{
PHOTOCATALYTIC DEGRADATION OF METHYLENE BLUE WITH SILVER DOPED ZnO NANOPARTICLES GROWN ON MICROSCOPIC SAND PARTICLES
}

\author{
(Degradasi Metilena Biru Menggunakan Nanopartikel ZnO Sebagai Fotomangkin yang \\ Didopkan dengan Perak Tumbuh di atas Pasir Bersaiz Mikro)
}

\author{
Nur Azmina Mohamed Safian ${ }^{1 *}$, Roslan Md Nor ${ }^{1}$, Hartini Ahmad Rafaie ${ }^{2}$, Siti Fairus Abdul Sani ${ }^{1}, Z_{\text {Zurina Osman }}^{1}$ \\ ${ }^{1}$ Department of Physics, Faculty of Sciences, \\ University of Malaya, 50603 Kuala Lumpur, Malaysia \\ ${ }^{2}$ Unit of Physics, School of Science, \\ Universiti Teknologi MARA Pahang, Jengka, 26400 Bandar Tun Abdul Razak, Jengka Pahang, Malaysia \\ *Corresponding author: nurazminasafian@siswa.um.edu.my
}

Received: 4 December 2016; Accepted: 1 December 2017

\begin{abstract}
Pure and $\mathrm{Ag}$ doped $\mathrm{ZnO}$ nanoparticles were synthesized on microscopic sand particles by sol-gel method. Silver nitrate was used as the doping precursor, $\mathrm{Ag}$ doping levels of 1.3 to 7.7 of $\mathrm{Ag} / \mathrm{Zn}$ ratios were obtained based on energy dispersive X-ray spectroscopy analysis. X-ray diffraction results show that a ZnO (101) peak of Ag doped samples are shifted towards lower degree which around $0.17^{\circ}$ compared to pure $\mathrm{ZnO}$ NPs, indicating the existence of doping in the Ag doped samples. The pure and $\mathrm{Ag}$ doped $\mathrm{ZnO}$ samples were used as photocatalysts in the degradation of methylene blue under UV irradiation. Photodegradation efficiency based on the pseudo-first kinetics model gave measured values of the photodegradation rate, $\mathrm{k}$ of 8.9, 11.8, 12.7, 14.8 and $17.4 \times 10^{-3} \mathrm{~min}^{-1}$ for pure, 1.3, 1.6, 1.7 and $2.4 \mathrm{of} \mathrm{Ag} / \mathrm{Zn}$ ratios, respectively. At higher doping levels of 3.3 and 7.7 of $\mathrm{Ag} / \mathrm{Zn}$ ratios, the $\mathrm{k}$ values receded to 12.7 and $12.0 \times 10^{-3} \mathrm{~min}^{-1}$, respectively. The increasing trend on $\mathrm{k}$ values can be due to the doping defect levels which trapped the recombining electrons, thus lengthening the lifetime of the electron hole pairs.
\end{abstract}

Keywords: photocatalysis, Ag doped $\mathrm{ZnO}$, nanoparticles

\begin{abstract}
Abstrak
Nanopartikel $\mathrm{ZnO}$ tulen dan nanopartikel $\mathrm{ZnO}$ yang didopkan dengan perak (Ag) telah disintesiskan di atas pasir bersaiz mikro menggunakan kaedah sol-gel. Argentum nitrat digunakan sebagai sumber Ag, dapatan tahap pendopan adalah 1.3 sehingga 7.7 nisbah Ag kepada Zn (Ag/Zn). Berdasarkan keputusan spektroskopi sinar-X, terdapat peralihan kedudukan puncak ZnO (101) sebanyak $0.17^{\circ}$ jika dibandingkan antara $\mathrm{ZnO}$ tulen dan sampel $\mathrm{ZnO}$ yang didopkan dengan Ag. Ini menunjukkan berlaku pendopan di dalam sampel nanopartikel $\mathrm{ZnO}$ yang didopkan dengan Ag. Semua sampel diuji sebagai fotomangkin di dalam degradasi metilena biru di bawah sinar UV. Kecekapan degradasi dikira menggunakan model kinetik pseudo-pertama dan memberikan nilai kadar degradasi, k iaitu masing-masing 8.9, 11.8, 12.7, 14.8 dan $17.4 \times 10^{-3} \mathrm{~min}^{-1}$ untuk sampel ZnO tulen, 1.3, 1.6, 1.7 dan 2.4 untuk nisbah $\mathrm{Ag} / \mathrm{Zn}$. Pada tahap pendopan yang tinggi iaitu 3.3 dan $7.7 \mathrm{Ag} / \mathrm{Zn}$, nilai k berkurangan kepada 12.7 dan $12.0 \times 10^{-3} \mathrm{~min}^{-1}$. Peningkatan nilai $\mathrm{k}$ adalah disebabkan oleh kesan pendopan di mana elektron terperangkap untuk pergabungan semula dan memangjangkan jangka hayat pasangan elektron dan lubang.
\end{abstract}

Kata kunci: fotomangkin, perak didopkan $\mathrm{ZnO}$, nanopartikel 


\section{Introduction}

Since 1972, the capability of $\mathrm{ZnO}$ in the degradation of wastewater has been studied [1]. Due to its remarkable features which has wide band gap $(3.37 \mathrm{eV})$ at room temperature and high exciton binding energy of approximately $60 \mathrm{meV}$ has made $\mathrm{ZnO}$ as a perfect candidate in photocatalyst application. To achieve high photocatalytic degradation efficiency of wastewater, $\mathrm{ZnO}$ photocatalyst must offer large specific surface area and a high efficiency for segregation photogenerated electron and holes. The most efficient way to accelerate the charge carrier separation by dope with noble metals. Silver (Ag) has been reported as the best element to dope with $\mathrm{ZnO}$ due to its high solubility [2] and can act as a sink to collect photogenerated electrons from the conduction band of $\mathrm{ZnO}$ [3]. Furthermore, Ag $4 \mathrm{~d}$ and oxygen $2 \mathrm{p}$ states were overlapped to form impurity band. This lead to the Fermi level shifted toward valence band and induced properties in $\mathrm{ZnO}$ [4].

Although there have many reports on the properties and photocatalysis efficiency of $\mathrm{Ag}$ doped $\mathrm{ZnO}$, there is still lack of understanding in details about photodegradation mechanism using $\mathrm{Ag}$ doped $\mathrm{ZnO}$. In this work, the differences of the photocatalytic degradation between $\mathrm{ZnO}$ and $\mathrm{Ag}$ doped $\mathrm{ZnO}$ on microscopic sand has been studied. Also, the effect of Ag ions on the morphology, defect and photocatalytic efficiency of all samples were investigated in detailed.

\section{Materials and Methods \\ Synthesis of Ag doped ZnO Nanoparticles on microscopic sand}

$\mathrm{ZnO}$ NPs growth on microscopic sand by simple seeded solution process using zinc acetate, $\mathrm{Zn}\left(\mathrm{O}_{2} \mathrm{CCH}_{3}\right)_{2}$ which was prepared in absolute ethanol at $0.0005 \mathrm{~mol}$ concentration. The sand were soaked for 5 minutes and then dry at $300{ }^{\circ} \mathrm{C}$ for 10 minutes. The process were repeated for three times before calcination process. Zinc nitrate hexahydrate $\left(\mathrm{Zn}\left(\mathrm{NO}_{3}\right)_{2} \cdot 6 \mathrm{H}_{2} \mathrm{O}\right)$ and hexamethylenetetramine (HMTA) were initially combined at the molar ratio of 1:1 in deionized water for growth solution. Then, silver nitrate hexahydrate $\left(\mathrm{AgNO}_{3}\right)$ were added in mixture solution at 1.0 to $3.5 \mathrm{~mol} \%$ with $0.5 \mathrm{~mol} \%$ increment. $5 \mathrm{~g}$ of the seeded sand were added in the doping solution and stirred continuously at $100{ }^{\circ} \mathrm{C}$ for 6 hours. After completing the growth process, the Ag doped ZnO NPs grown on sand were wash and rinsed several times thoroughly in DI water and calcined at $300{ }^{\circ} \mathrm{C}$ for 2 hours.

\section{Characterization of Ag doped ZnO Nanoparticles}

The as-prepared $\mathrm{Ag}$ doped $\mathrm{ZnO}$ NPs grown on sand were examined by several characterization techniques. The elemental of as-prepared nanomaterials were characterized by energy dispersive spectroscopy (EDX - JSM 7600-F). The morphologies were examined by field emission scanning electron microscopy (FESEM - JSM 7600-F). The crystallinity and optical properties of ZnO NPs samples were studied by X-ray diffractometer (XRD EMPYREAN, PANalytical) and photoluminescence (PL-In-Via Raman Microscope) spectroscopy, respectively.

\section{Photocatalytic degradation of methylene blue using Ag doped ZnO nanoparticles}

The photocatalytic performances of the samples were evaluated by the decomposition of $0.5 \mathrm{mg} / 100 \mathrm{ml}$ methylene blue solution under UV light at $254 \mathrm{~nm}$ wavelength. An amount $1 \mathrm{~g}$ of samples were added in the MB solution and placed in the dark mood for 30 minutes before switching the UV lamp (6 Watt, UVGL-58). Afterwards, absorption spectra of the MB solutions were taken and analyzed by ultraviolet-visible (UV-Vis - EVOLUTION 201, Thermo Scientific) spectroscopy.

\section{Results and Discussion}

The present of $\mathrm{Ag}$ element in the $\mathrm{ZnO}$ samples grown on microscopic sand were evidenced by EDX spectra as shown in Figure 1. The amount of $\mathrm{Ag}$ doped $\mathrm{ZnO}$ were calculated by atomic percent (at. \%) which leads to 1.3, 1.6, 1.7, 2.4, 3.3 and 7.7 of $\mathrm{Ag} / \mathrm{Zn}$ ratios for 1.0, 1.5, 2.0, 2.5, 3.0 and $3.5 \mathrm{~mol} \%$, respectively as tabulated in Table 1. As the amount of $\mathrm{Ag}$ doped increases, a strong peak of $\mathrm{Ag}_{\mathrm{L} \alpha}$ and $\mathrm{Ag}_{\mathrm{L} \beta}$ appeared in $\mathrm{ZnO}$ samples at 2.97 and $2.98 \mathrm{KeV}$ especially for $\mathrm{ZnO} 3.3$ and 7.7 of $\mathrm{Ag} / \mathrm{Zn}$ ratio samples. 


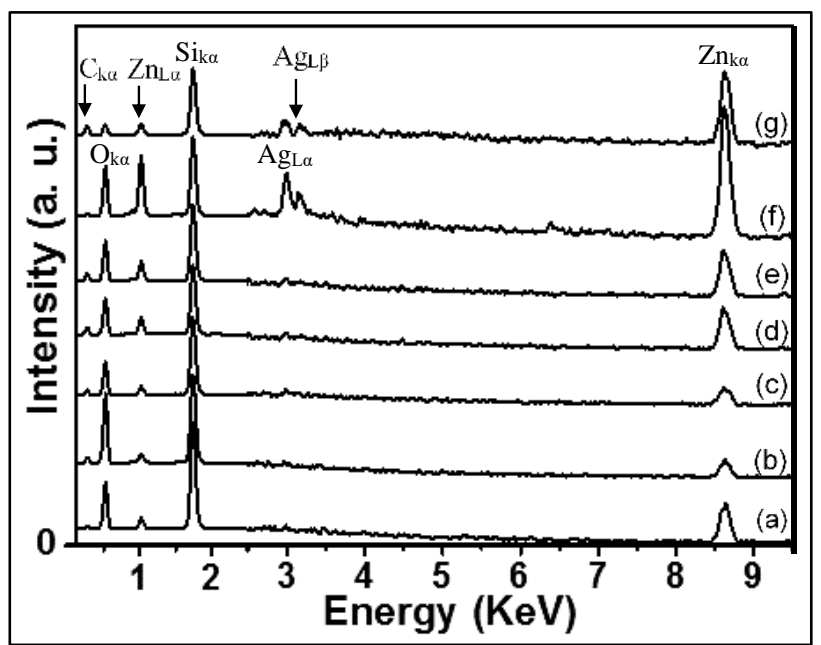

Figure 1. EDX spectra of (a) pure ZnO NPs and Ag doped ZnO NPs grown on microscopic sand at (b) 1.0, (c) 1.5, (d) 2.0 , (e) 2.5 , (f) 3.0 and (g) $3.5 \mathrm{~mol} \%$ of $\mathrm{AgNO}_{3}$

Table 1. The summary of elements composition of pure and Ag doped ZnO NPs grown on microscopic sand based on EDX analysis

\begin{tabular}{|c|c|c|c|c|c|c|}
\hline \multirow{2}{*}{\multicolumn{2}{|c|}{ Samples }} & \multicolumn{4}{|c|}{ At. $\%$} & \multirow{3}{*}{$\frac{[\mathbf{A g}] /[\mathbf{Z n}] \times 100}{0}$} \\
\hline & & \multirow{2}{*}{$\begin{array}{c}\mathrm{O} \\
36.39\end{array}$} & \multirow{2}{*}{$\begin{array}{c}\mathrm{Si} \\
43.54\end{array}$} & \multirow{2}{*}{$\begin{array}{c}\mathrm{Zn} \\
7.13\end{array}$} & \multirow{2}{*}{$\begin{array}{c}\mathrm{Ag} \\
-\end{array}$} & \\
\hline (a) & pure $\mathrm{ZnO}$ NPs & & & & & \\
\hline (b) & $1.0 \mathrm{~mol} \% \mathrm{AgNO}_{3}$ & 59.54 & 26.90 & 1.55 & 0.02 & 1.3 \\
\hline (c) & $1.5 \mathrm{~mol} \% \mathrm{AgNO}_{3}$ & 45.22 & 36.65 & 3.72 & 0.06 & 1.6 \\
\hline (d) & $2.0 \mathrm{~mol} \% \mathrm{AgNO}_{3}$ & 54.53 & 24.85 & 7.05 & 0.12 & 1.7 \\
\hline (e) & $2.5 \mathrm{~mol} \% \mathrm{AgNO}_{3}$ & 48.48 & 28.03 & 2.09 & 0.05 & 2.4 \\
\hline (f) & $3.0 \mathrm{~mol} \% \mathrm{AgNO}_{3}$ & 53.92 & 21.68 & 11.84 & 0.39 & 3.3 \\
\hline (g) & $3.5 \mathrm{~mol} \% \mathrm{AgNO}_{3}$ & 22.90 & 18.93 & 2.60 & 0.20 & 7.7 \\
\hline
\end{tabular}

The images of surface morphology, particles sizes and shape of the ZnO and Ag doped ZnO NPs grown on sand were obtained by FESEM as shown in Figure 2. High density of the ZnO and Ag doped ZnO NPs were observed throughout the sand surface with the sizes of particles in the range of tens to hundreds of nanometers. From the observation, most of the particles in the $\mathrm{ZnO}$ and $\mathrm{Ag}$ doped $\mathrm{ZnO}$ NPs samples were exhibited spindles-like shape which has wide in the middle and tapers at both ends. The particles sizes were found to be mixed between small and large particles in the 2.4 of $\mathrm{Ag} / \mathrm{Zn}$ ratio sample as shown in Figure 2(e). These small particles might increase the surface area of $\mathrm{Ag}$ doped $\mathrm{ZnO}$ samples which will enhance its light absorption and improve its photocatalytic activity. The images also show that the particles sizes of $\mathrm{Ag}$ doped $\mathrm{ZnO}$ seem like become bigger at high $\mathrm{Ag}$ content. The changes in particles sizes was believed due to the aggregation of $\mathrm{Ag}$ and $\mathrm{Zn}$ particle into bigger cluster. This can cause decreased light utilization rate and led to low photocatalytic activity. The biggest particles diameters were measured in the $\mathrm{Ag}$ doped $\mathrm{ZnO}$ at 7.7 of $\mathrm{Ag} / \mathrm{Zn}$ ratio which around 223 to $225 \mathrm{~nm}$. 

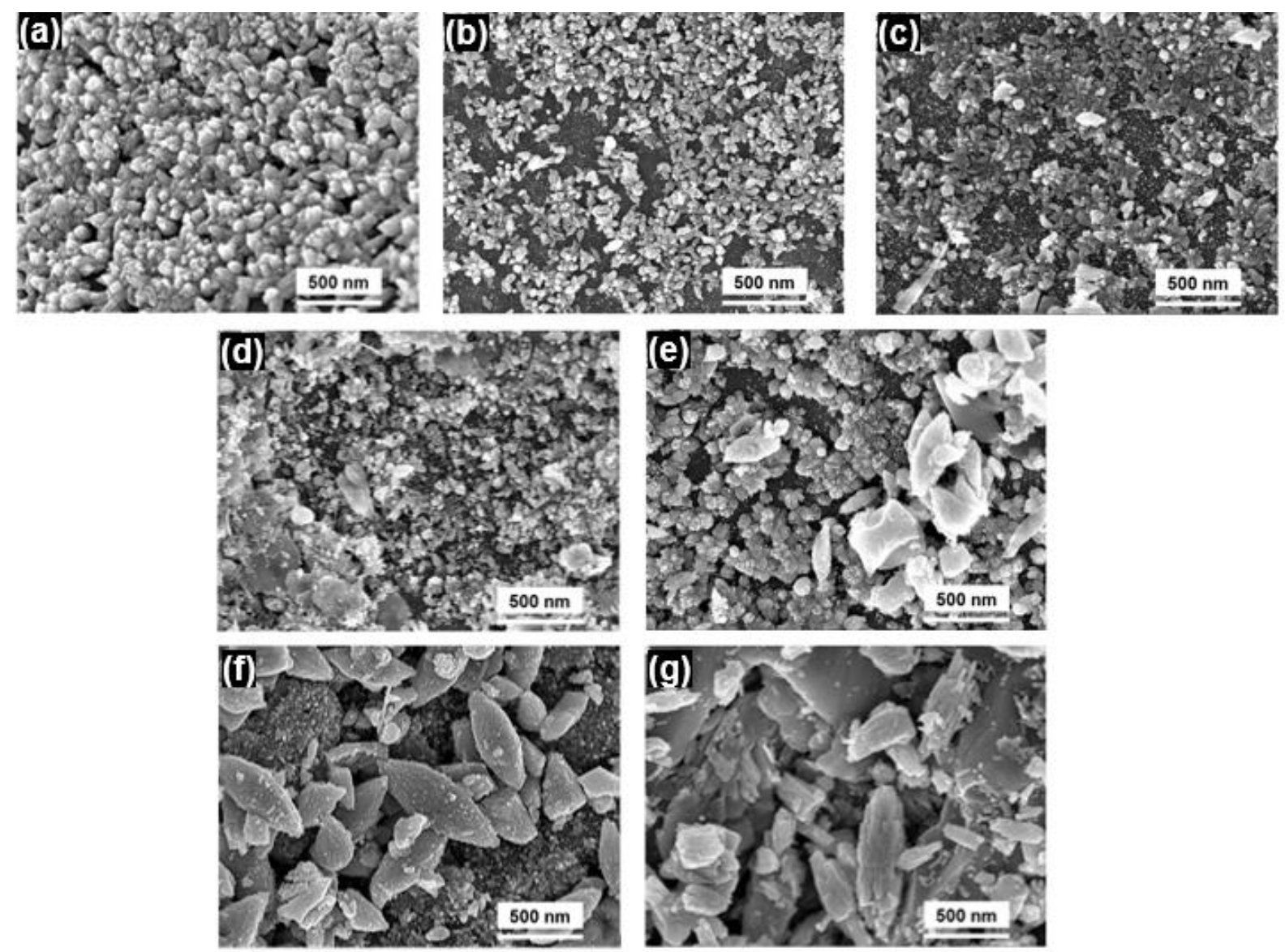

Figure 2. FESEM images of as-synthesized (a) pure ZnO NPs, (b) 1.3, (c) 1.6, (d) 1.7, (e) 2.4, (f) 3.3 and (g) 7.7 of $\mathrm{Ag} / \mathrm{Zn}$ ratios

The typical XRD patterns of pure $\mathrm{ZnO}$ nanoparticles and $\mathrm{Ag}$ doped $\mathrm{ZnO}$ grown on sand are illustrated in Figure 3(a). Clearly, all samples showed common $\mathrm{ZnO}$ peaks at $31.8^{\circ}, 34.4^{\circ}, 36.3^{\circ}, 47.6^{\circ}, 56.7^{\circ}, 62.9^{\circ}, 66.4^{\circ}$ and $69.2^{\circ}$. The peaks position can be indexed to the wurtzite crystal ZnO structure (JCPDS File No. 01-79-2205) and correspond to (100), (002), (101), (102), (110), (103), (200) and (201), respectively. The others peaks at $39.7^{\circ}, 40.4^{\circ}, 42.6^{\circ}, 45.9^{\circ}$, $50.4^{\circ}, 55.1^{\circ}$ and $60.1^{\circ}$ can be indexed to the (012), (111), (200), (201), (134), (022) and (211) reflection planes of quartz based on the JCPDS file no. 46-1045. Figure 3(b) shows an enlarged view of XRD patterns of ZnO and Ag doped $\mathrm{ZnO}$ grown on microscopic sand. Noting that the peak position of (101) reflection peak had shifted toward lower values as the $\mathrm{Ag}$ dopant increases. The shift might be due to the partial substitution of $\mathrm{Ag}^{+}$in the $\mathrm{ZnO}$ lattice and causes the increases of lattice constant a and $\mathrm{c}[5,6]$. This occurred probably related to the differentiation of ionic radii between $\mathrm{Ag}^{+}$and $\mathrm{Zn}^{2+}$ ions which $1.22 \AA$ and $0.74 \AA$, respectively. 

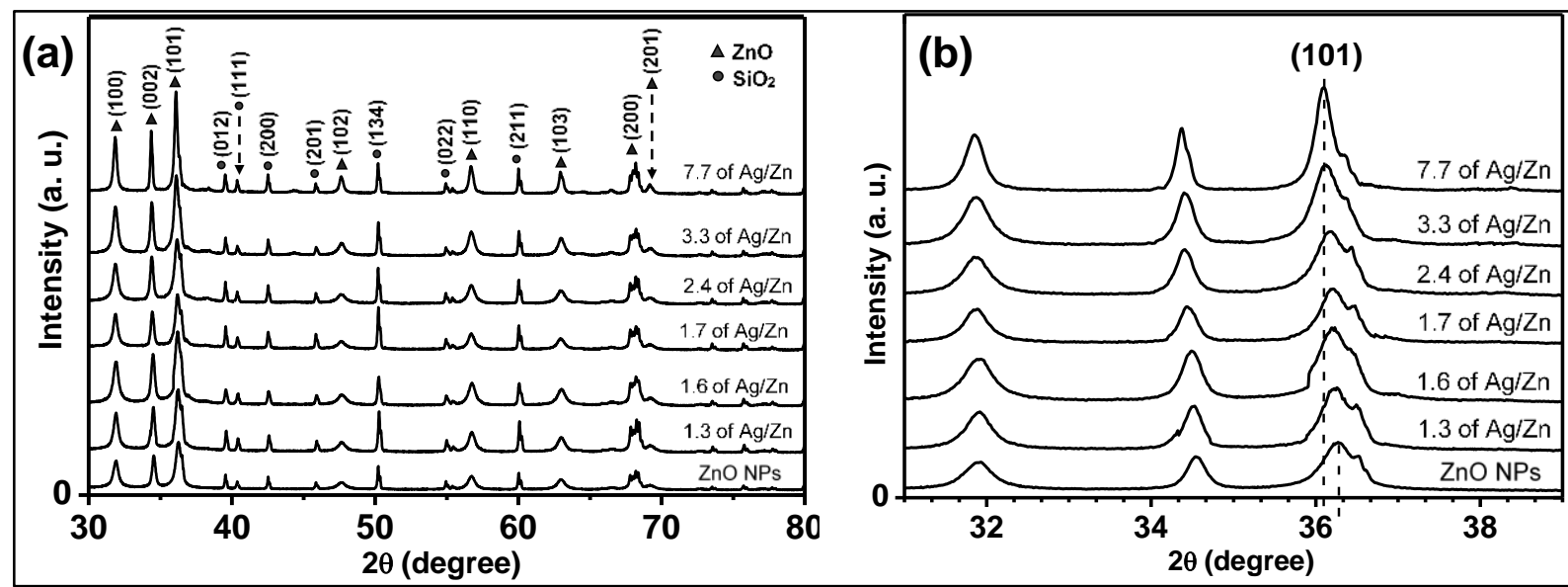

Figure 3. (a) Full range of XRD patterns and (b) shift detail of $\mathrm{ZnO}$ (101) peak of $\mathrm{ZnO}$ and $\mathrm{Ag}$ doped $\mathrm{ZnO}$ grown on sand

Figure 4 shows the photoluminescence spectra of pure and Ag doped ZnO sample in the range of 200 to $900 \mathrm{~nm}$. There are two peaks showed in PL spectra which the obvious and broad peak was appeared at 500 to $800 \mathrm{~nm}$ and small peak was appeared at round 350 to $420 \mathrm{~nm}$ as shown in inset graph in Figure 4 . The small peaks below 420 $\mathrm{nm}$ were indicated as near-band-edge (NBE) emission which associated with exciton emission which obtained in $\mathrm{ZnO}$ and 2.4 of $\mathrm{Ag} / \mathrm{Zn}$ ratio sample. The NBE emission usually caused by band structural deformation resulting from lattice deformation [7]. This peak which are attributed to the reduction of oxygen interstitials at $\mathrm{ZnO}$ surface [8]. By reducing the defect of oxygen interstitials, it might enhanced the photocatalytic activity of $\mathrm{ZnO}$ as photocatalyst. The center of these peaks position were obtained at $394 \mathrm{~nm}$ for ZnO NPs and $404 \mathrm{~nm}$ for 2.4 of $\mathrm{Ag} / \mathrm{Zn}$ ratio sample.

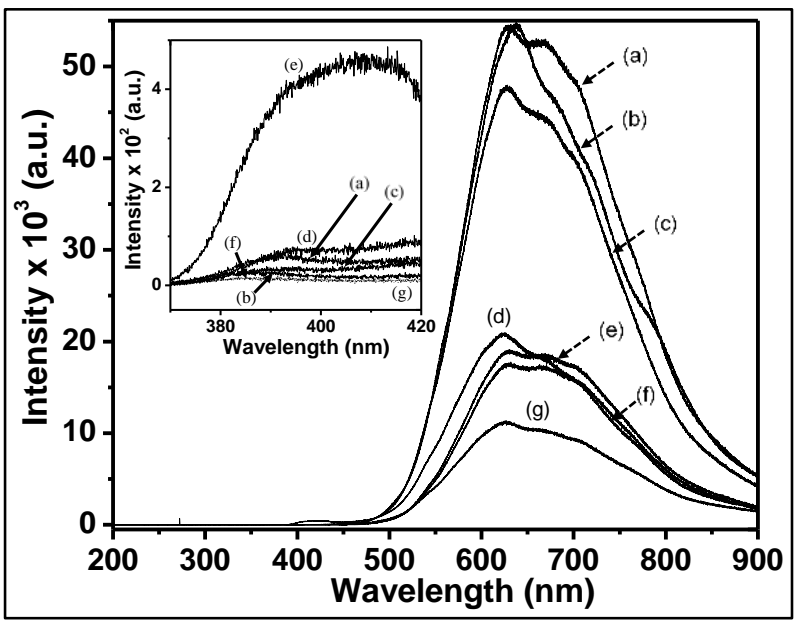

Figure 4. Full range PL spectra from 300 to $900 \mathrm{~nm}$. The inset graph shows enlargement PL spectra at range 370 to $490 \mathrm{~nm}$ of (a) pure $\mathrm{ZnO} N P s$, (b) 1.3 , (c) 1.6, (d) 1.7, (e) 2.4, (f) 3.3 and (g) 7.7 of Ag/Zn ratios

The broad peak at range 500 to $800 \mathrm{~nm}$ in the PL spectra was called as deep level emission. The deep level emission is usually related to the structural defect and impurities of samples [7]. Figure 5 (a) to (g) show the deep level emission for pure $\mathrm{ZnO}$ NPs, 1.3, 1.6, 1.7, 2.4, 3.3 and 7.7 of Ag/Zn ratio samples, respectively. The fitting of broad spectrum was done using Gaussian distribution which shows four major peaks around 553 to $567 \mathrm{~nm}, 608$ to $614 \mathrm{~nm}$, 653 to 684 and 713 to $780 \mathrm{~nm}$. The peak around 553 to $567 \mathrm{~nm}$ was believed attributed to the transition of zinc 
interstitial to zinc vacancies. While two peaks at range $608-614 \mathrm{~nm}$ and $653-674 \mathrm{~nm}$ were known as orange-yellow and orange-red emission respectively, obtained due to the structural defect and single ionized vacancy $[9,10]$ as well as oxygen interstitial [11]. The single negatively charged interstitial oxygen ion inside the lattice occurs due to the loss of oxygen ions within the crystal lattice [12]. The last peak around 713 to $780 \mathrm{~nm}$ was appeared which corresponding to the oxygen vacancies and zinc interstitials [13].

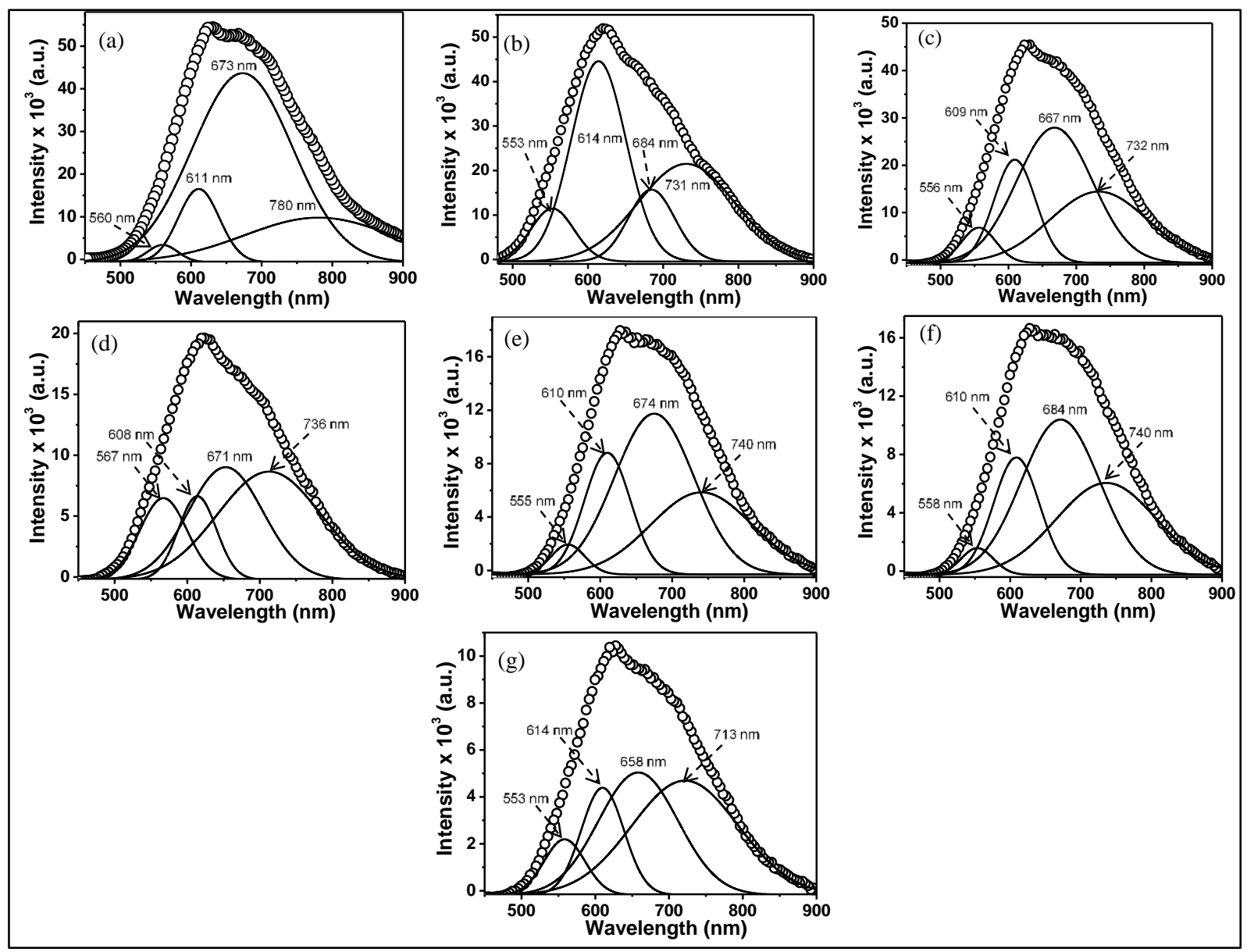

Figure 5. Gaussian fitted PL spectrum of (a) pure $\mathrm{ZnO} \mathrm{NPs}$, (b) 1.3 (c) 1.6, (d) 1.7, (e) 2.4, (f) 3.3 and (g) 7.7 of $\mathrm{Ag} / \mathrm{Zn}$ ratios

The absorption spectra of photodegradation $100 \mathrm{ml} \mathrm{MB}$ solution using (a) pure $\mathrm{ZnO}$ and $\mathrm{Ag}$ doped $\mathrm{ZnO}$ at (b) 1.3, (c) 1.6, (d) 1.7, (e) 2.4, (f) 3.3 and (g) 7.7 of Ag/Zn ratios under UV light irradiation for 150 mins are shown in Figure 6. The UV-vis spectra was seen to be similar for all samples which is the tremendous peak of MB dye was appeared at $664 \mathrm{~nm}$. The intensity of peak at $664 \mathrm{~nm}$ were gradually decreased with each 15 minutes increment irradiation time. The curve of absorption for 2.4 of $\mathrm{Ag} / \mathrm{Zn}$ ratio of $\mathrm{Ag}$ doped $\mathrm{ZnO}$ photocatalyst at 150 minutes irradiation time was shows nearly horizontal meaning the MB solution was almost completely degrade. 


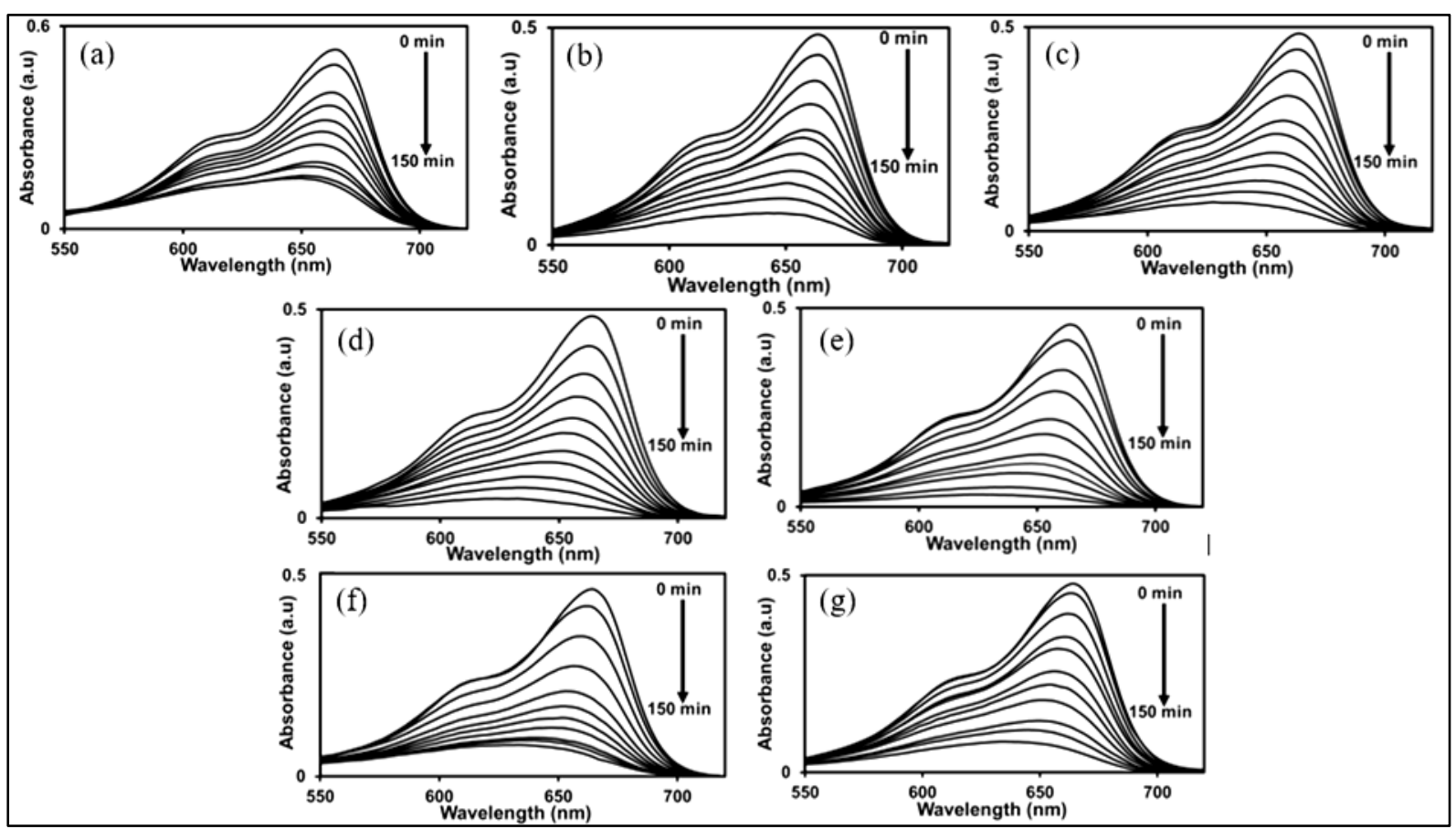

Figure 6. UV-vis absorption spectra of photodegradation $100 \mathrm{ml}$ of $5 \mathrm{mg} / \mathrm{l} \mathrm{MB}$ solution under UV lamp irradiation using: (a) pure $\mathrm{ZnO} \mathrm{NPs}$, (b) 1.3 (c) 1.6, (d) 1.7, (e) 2.4, (f) 3.3 and (g) 7.7 of $\mathrm{Ag} / \mathrm{Zn}$ ratios as photocatalysts

Figure 7(a) shows the photodegradation efficiency (\%) for 150 minutes irradiation time for all samples. The highest photodegradation efficiency was calculated at 2.4 of $\mathrm{Ag} / \mathrm{Zn}$ ratio sample which was $93.3 \%$. Then followed by 1.7 , 1.6, 1.3, 7.7 and 3.3 of $\mathrm{Ag} / \mathrm{Zn}$ ratio samples which were $90.4 \%, 85.3 \%$. 84.8\%, 83.6\% and 83.1\%, respectively. The lowest photodegradation efficiency was obtained from pure $\mathrm{ZnO}$ sample which around $71.7 \%$. Based on results, it clearly demonstrated that $\mathrm{ZnO}$ doped with $\mathrm{Ag}$ degrades dye more efficiently than pure $\mathrm{ZnO}$. It is evident that doping of $\mathrm{ZnO}$ with transition metals like $\mathrm{Ag}$ enhances photocatalytic activities of $\mathrm{ZnO}$. However, further increasing the $\mathrm{Ag}$ content in the $\mathrm{ZnO}$ samples show decreases of photocatalytic activity as obtained at 3.3 and $7.7 \mathrm{of} \mathrm{Ag} / \mathrm{Zn} \mathrm{ratio}$ samples. It was believed due to the existence of bulk defects which the only ones have bad effects on the photocatalytic activity [14]. The agglomeration of small particles into bigger clusters has formed impurities or bulk defect as confirmed by FESEM analysis. Consequently, decreased the surface area of photocatalyst and decelerates the oxidation and reduction process of MB solution.

The photodegradation rate constant, $\mathrm{k}$ of pure $\mathrm{ZnO}$ and $\mathrm{Ag}$ doped $\mathrm{ZnO}$ NPs samples were obtained by plotting ln $\left(\mathrm{C} / \mathrm{C}_{\mathrm{o}}\right)$ against irradiation time as shown in Figure $7(\mathrm{~b})$. The linear plots revealed that the photodegradation of $\mathrm{MB}$ has follow pseudo-first order reaction kinetics. The lowest value of $\mathrm{k}$ was calculated at pure $\mathrm{ZnO}$ NPs sample which $8.9 \times 10^{-3} \mathrm{~min}^{-1}$ then as dopant increase from 1.3 to 2.4 of $\mathrm{Ag} / \mathrm{Zn}$ ratio, the value of $\mathrm{k}$ has been increased from 11.8 to $17.4 \times 10^{-3} \mathrm{~min}^{-1}$ as shown in Figure 7(c). The value of $\mathrm{k}$ then decreases as increase the Ag content in $\mathrm{ZnO}$ sample which around 12.7 to $12.0 \times 10^{-3} \mathrm{~min}^{-1}$ at 3.3 and 7.7 of $\mathrm{Ag} / \mathrm{Zn}$ ratio sample, respectively. At the optimum Ag content which was 2.4 of $\mathrm{Ag} / \mathrm{Zn}$ ratio, the $\mathrm{Ag}$ particles that deposited with the $\mathrm{ZnO}$ can act as electron-hole separation center. The electron might be transfer from the $\mathrm{ZnO}$ conduction band to metallic silver particles at interface. In contrast, high Ag dopant is detrimental to the photodegradation efficiency which the Ag particles can act as electron hole recombination center, thereby decreasing the photocatalytic activity of $\mathrm{ZnO}$. 


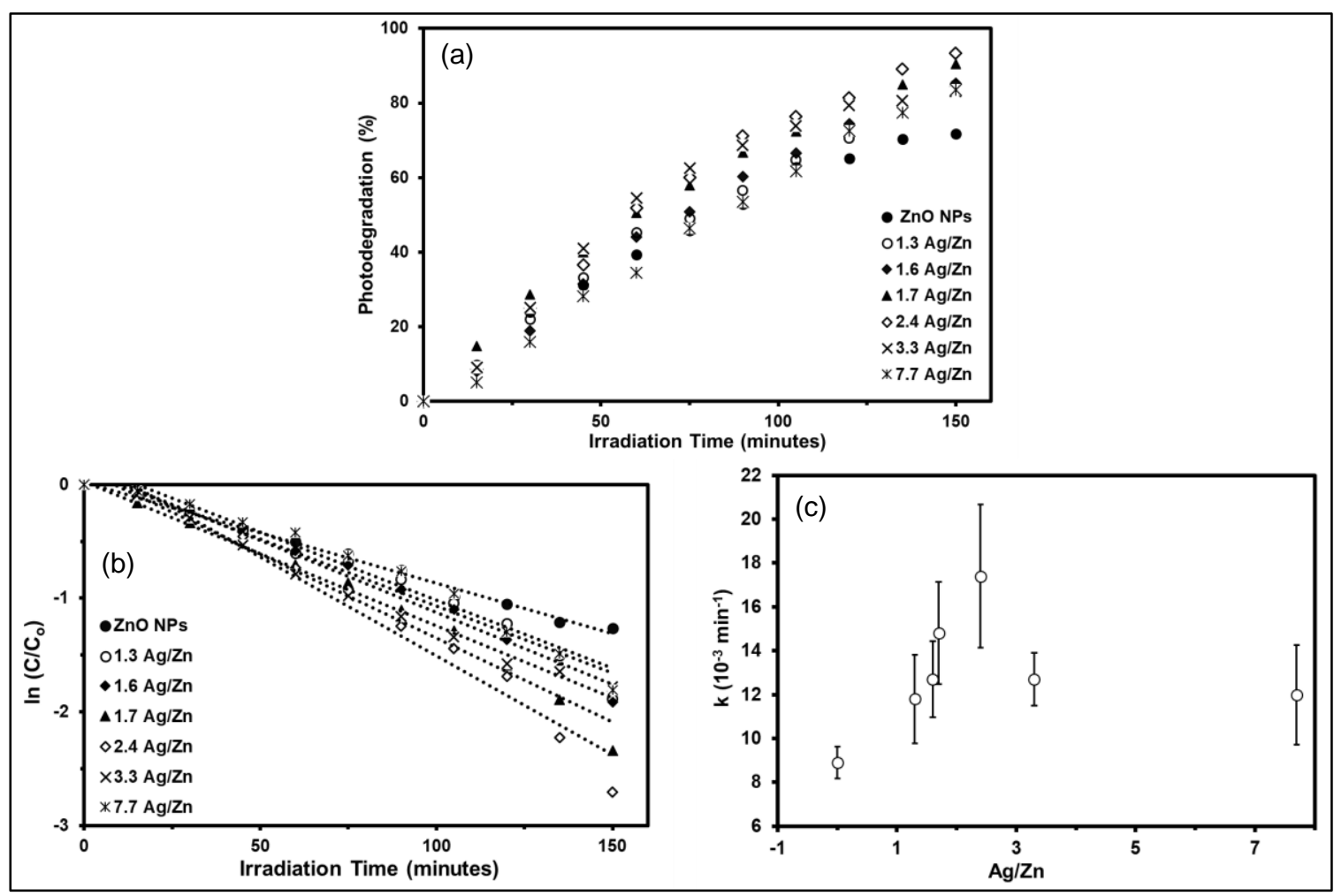

Figure 7. (a) The percentage of photodegradation MB solution for 150 minutes. (b) Linear plots of $\ln \left(C / C_{0}\right)$ for the photodegradation of $\mathrm{MB}$ in the presence of sand- $\mathrm{ZnO}$ and $\mathrm{Ag}$ doped $\mathrm{ZnO}$ samples and (c) the changes of $\mathrm{k}$ values as a function of $\mathrm{Ag}$ content.

\section{Conclusion}

$\mathrm{Ag}$ doped $\mathrm{ZnO}$ with varied $\mathrm{Ag}$ content from 1.3 to $7.7 \mathrm{Ag} \mathrm{Ag} / \mathrm{Zn}$ ratios has been successfully synthesized on the microscopic sand. The EDX has shown the existence of Ag element in the samples and the shifted $\mathrm{ZnO}$ [101] peak of $\mathrm{XRD}$ has proven that the Ag particles has been doped in the $\mathrm{ZnO}$ samples. The FESEM images show that the diameters and structures of $\mathrm{ZnO}$ were slightly change to bigger sizes as increases of $\mathrm{Ag}$ dopant. The defects introduce additional states in the band gap of $\mathrm{ZnO}$ which act as electron trapping centers and contributed in the prolonging a lifetime of charge carriers. The photocatalytic activity for $\mathrm{Ag}$ doped $\mathrm{ZnO}$ at $2.4 \mathrm{of} \mathrm{Ag} / \mathrm{Zn}$ ratio has increase was almost twice compared to the pure $\mathrm{ZnO}$ which from 8.9 to $17.4 \times 10^{-3} \mathrm{~min}^{-1}$. Therefore, the Ag doped $\mathrm{ZnO}$ samples grown on sand had shown very interesting characteristics and promising as good photocatalytic agent as well as has good potential for application on the water purification especially in industrial sector.

\section{Acknowledgement}

The authors are grateful to the Institute of Research Management and Monitoring, University of Malaya for providing a postgraduate research grant (Project Code: PG110-2015A) and Department of Physics, University of Malaya for financial and facilities support of this work.

\section{References}

1. Tanaka, K. and Blyholder, G. (1972). Photocatalytic reactions on zinc oxide. III. Hydrogenation of ethylene. The Journal of Physical Chemistry, 76(10): 1394-1397.

2. Yan, Y., Al-Jassim, M. M. and Wei, S. H. (2006). Doping of $\mathrm{ZnO}$ by Group-IB elements. Applied physics letters, 89(18): 181912.

3. Ren, C., Yang, B., Wu, M., Xu, J., Fu, Z., Guo, T., Zhao, Y. and Zhu, C. (2010). Synthesis of Ag/ZnO nanorods array with enhanced photocatalytic performance. Journal of Hazardous materials, 182(1): 123-129. 
4. Hosseini, S. M., Sarsari, I. A., Kameli, P. and Salamati, H. (2015). Effect of Ag doping on structural, optical, and photocatalytic properties of $\mathrm{ZnO}$ nanoparticles. Journal of Alloys and Compounds, 640: 408-415.

5. Karunakaran, C., Rajeswari, V. and Gomathisankar, P. (2011). Combustion synthesis of ZnO and Ag-doped $\mathrm{ZnO}$ and their bactericidal and photocatalytic activities. Superlattices and Microstructures, 50(3): $234-241$.

6. Amornpitoksuk, P., Suwanboon, S., Sangkanu, S., Sukhoom, A., Muensit, N. and Baltrusaitis, J. (2012). Synthesis, characterization, photocatalytic and antibacterial activities of Ag-doped $\mathrm{ZnO}$ powders modified with a diblock copolymer. Powder Technology, 219: 158-164.

7. Tamargo, M. C. (2002). II-VI semiconductor materials and their applications (Vol. 12). CRC Press.

8. Sun, W. C., Yeh, Y. C., Ko, C. T., He, J. H. and Chen, M. J. (2011). Improved characteristics of near-bandedge and deep-level emissions from $\mathrm{ZnO}$ nanorod arrays by atomic-layer-deposited $\mathrm{Al}_{2} \mathrm{O}_{3}$ and $\mathrm{ZnO}$ shell layers. Nanoscale Research Letters, 6(1): 556.

9. Vanheusden, K., Warren, W. L., Seager, C. H., Tallant, D. R., Voigt, J. A. and Gnade, B. E. (1996). Mechanisms behind green photoluminescence in ZnO phosphor powders. Journal of Applied Physics, 79 (10): 7983-7990.

10. Wu, J. J. and Liu, S. C. (2002). Low-temperature growth of well-aligned $\mathrm{ZnO}$ nanorods by chemical vapor deposition. Advanced Materials, 14(3): 215-218.

11. Liu, M., Kitai, A. H. and Mascher, P. (1992). Point defects and luminescence centres in zinc oxide and zinc oxide doped with manganese. Journal of Luminescence, 54(1): 35-42.

12. Wu, X. L., Siu, G. G., Fu, C. L. and Ong, H. C. (2001). Photoluminescence and cathodoluminescence studies of stoichiometric and oxygen-deficient ZnO films. Applied Physics Letters, 78(16): 2285-2287.

13. Djurišić, A. B., Leung, Y. H., Tam, K. H., Hsu, Y. F., Ding, L., Ge, W. K., Zhong, Y. C., Wong, K. S., Chan, W. K., Tam, H. L. and Cheah, K. W. (2007). Defect emissions in ZnO nanostructures. Nanotechnology, 18(9): 095702.

14. Kong, M., Li, Y., Chen, X., Tian, T., Fang, P., Zheng, F. and Zhao, X. (2011). Tuning the relative concentration ratio of bulk defects to surface defects in $\mathrm{TiO}_{2}$ nanocrystals leads to high photocatalytic efficiency. Journal of the American Chemical Society, 133(41): 16414-16417. 